\title{
LİTYUM KLORİT/DİMETİLASETAMİT ORTAMINDA NANOSELÜLOZUN ASETIKK ANHİDRİT VE FARKLI YAĞ ASİTLERİ İLE ESTERIFIIKASYONUNUN OPTİMİZASYONU
}

\author{
Özlem Erinç ${ }^{1 *}$, Hakan Erinç ${ }^{1}$, Behiç Mert $^{2}$, Ayşe Özbey ${ }^{1}$ \\ ${ }^{1}$ Niğde Ömer Halisdemir Üniversitesi, Mühendislik Fakültesi, Gıda Mühendisliği Bölümü, Niğde, Türkiye \\ 2 Orta Doğu Teknik Üniversitesi, Mühendislik Fakültesi, Gıda Mühendisliği Bölümü, Ankara, Türkiye \\ Geliş / Received: 22.09.2021; Kabul / Accepted: 29.11.2021; Online bask1 / Published online: 15.11.2021 \\ Erinç, Ö., Erinç, H., Mert, B., Özbey, A. (2021). Lityum klorit/dimetilasetamit ortamında nanoselülozun \\ asetik anhidrit ve farklı yağ asitleri ile esterifikasyonunun optimizasyonu. GIDA (2021) 46 (6) 1467-1480 \\ doi: $10.15237 /$ gida.GD21118.
}

Erinc, Ö., Erinc, H., Mert, B., Özbey, A. (2021). Optimization of nanocellulose esterification with different fatty acids and acetic anbydride in lithium chloride / dimethylacetamide medium. GIDA (2021) 46 (6) 1467-1480 doi: 10.15237/ gida.GD21118.

\section{ÖZ}

Sunulan bu çalışmada buğday kepeği, mısır koçanı ve ayçiçeği tablasından mikro-akışkan tekniği kullanılarak nanolifler elde edildikten sonra farklı zincir uzunluklarına sahip yağ asitleri (C6, C12, C18, C18:1) ile farklı derecelerde esterleştirilmesinin optimizasyonu yapılmıştır. İlk olarak, selülozik materyal $\mathrm{NaOH}$ ile muamele edildi ve daha sonra nano-selüloz lifi elde etmek için kolloid değirmen ve mikro akışkanlaşturıcıda öğütüldü. $\mathrm{Bu}$ liflerde selüloz, lignin ve su tutma kapasitesi analizleri yapılmıştır. Örneklerin selüloz içeriği arttıkça su tutma kapasitelerinin arttı̆̆ belirlendi. Bu lifler, farklı esterleşme derecelerinde nanoselüloz-yağ asidi esterleri elde etmek için farklı yağ asitleri ile esterleştirildi. Bu sayede, farklı hidrofilik ve lipofilik gruplara sahip nanoselüloz yağ asidi esterleri elde edildi (esterleşme dereceleri 0,41-2,99). Reaksiyon süresinin ve kullanılan yağ asidi miktarının arttırılması, esterleşme reaksiyonunun yüksek oranda gerçekleşmesini sağladı. Maksimum esterleşme derecesine sahip ürünler, $90^{\circ} \mathrm{C}^{\prime}$ de 300 dakika sonunda anhidroglükoz birimi başına ortalama 2.45 asetil grubu ve 0.55 yağ asidi olarak elde edildi. Sonuç olarak, selülozun farklı yağ asitleri ve asetik anhidrit ile DMAc/LiCl ortamında farklı derecelerde esterleştirilmesi sağlandı.

Anahtar kelimeler: Nanoselüloz, esterifikasyon, yağ asitleri, asetik anhidrit

\section{OPTIMIZATION OF NANOCELLULOSE ESTERIFICATION WITH DIFFERENT FATTY ACIDS AND ACETIC ANHYDRIDE IN LITHIUM CHLORIDE/DIMETHYLACETAMIDE MEDIUM}

\begin{abstract}
In this study, nano fibers were obtained from wheat bran, corn cob and sunflower receptacle by using micro-fluidization and then esterified with fatty acids (C6, C12, C18, C18:1) in different degrees of substitution. Firstly, cellulosic material was treated with $\mathrm{NaOH}$ and then milled through the colloid mill and micro-fluidizer to obtain nano-cellulose fiber. Cellulose, lignin and water holding capacity
\end{abstract}

\footnotetext{
${ }^{*}$ Yazışmalardan sorumlu yazar / Corresponding author

17: ozlem_erinc@hotmail.com (1): (+90) 3882254005

且: (+90) 3882250112
}

Özlem Erinç; ORCID no: 0000-0001-7968-000X

Hakan Erinç; ORCID no: 0000-0001-8858-4570

Behiç Mert; ORCID no: 0000-0001-8450-8810

Ayşe Özbey; ORCID no: 0000-0003-3210-4077 
analyzes were made in these fiber. It was determined that as the cellulose content of the samples increased, their water holding capacity increased. These fibers were esterified with different fatty acids in different degrees of substitution to obtain nanocellulose-fatty acid esters. In this way, nanocellulose-fatty acid esters with different hydrophilic and lipophilic groups were obtained (degrees of substitution 0,41-2,99). Increasing the reaction time and increasing the amount of fatty acid used ensured that the esterification reaction took place at a high rate. Products with the maximum degree of esterification were obtained after 300 minute at $90^{\circ} \mathrm{C}$ with an average of 2.45 acetyl groups and 0.55 fatty substituents per anhydroglucose unit. As a result, cellulose was esterified with different fatty acids and acetic anhydride in $\mathrm{DMAc} / \mathrm{LiCl}$ medium at different degrees.

Keywords: Nanocellulose, esterification, fatty acids, acetic anhydride

\section{GİRIŞ̧}

Selüloz doğadaki en çok bulunan, Danhidroglukopiranoz birimi (AGU) içeren doğrusal ve oldukça sert bir homopolimerdir. Selülozun yapısal özelliklerinin iyi bir şekilde anlaşılması, farklı ikame edicilerin selüloz ve türevlerinin fiziksel ve kimyasal özellikleri üzerindeki etkisini incelemeyi gerektirir. Anselme Payen, selülozun kimyasal bileşimini $\left(\mathrm{C}_{6} \mathrm{H}_{10} \mathrm{O}_{5}\right)_{\mathrm{n}}$ ilk belirleyen kişidir (Wisniak, 2004). Tekrar birimi, $\beta-1 \rightarrow 4$ glikosidik bağ ile birbirine bağlanmış iki AGU halkasından $\left(\left(\mathrm{C}_{6} \mathrm{H}_{10} \mathrm{O}_{5}\right)_{n} ; \mathrm{n}=\right.$ 10000 ile 15000, n, selüloz kaynağına bağlı) oluşmaktadır. İntramoleküler hidrojen bağları selüloz molekülünün yüksek sertlik ve sağlamlığının başlıca nedeni olup çözeltide yüksek viskozite, yüksek kristalleşme eğilimi ve lifimsi şeritler oluşturma kabiliyetini sağlar (Kondo, 1997).

Selüloz yaygin olarak kullanılan organik çözücülerde ve su içerisinde çözünmez (Krässig, 1992). Bunun nedeni hem geniş moleküller aras1 ve molekül içi hidrojen bağlarının bulunması hem de hidrofobik etkileşimlerdir. Hidrojen bağlarının kırrlması, polar ve polar olmayan çözücülerdeki selülozun çözünürlügünü arttırır (Medronho vd., 2012).

Selüloz morfolojik olarak iyi düzenlenmiş lifli bir yapıya sahiptir. Selüloz morfolojisi üzerine bilgi çoğunlukla elektron mikroskobisi teknikleriyle (tarama ve transmisyon elektron mikroskobu) elde edilir. Selülozun kaynağına bağlı olarak değişken boyutlu en küçük morfolojik birimi lifleridir. Üniform ve düzgün olmayan bir lifin çapı 3-20 nm aralığındadır. Mikrolif, düzgün olmayan alt birimlerden oluşmasına rağmen, en iyi tanımlanmış en küçük morfolojik selüloz yapısıdır. Mikrolifler, çapları 10-50 nm arasında olan ve önemli ölçüde selüloz kökenli olan daha büyük morfolojik yapılar şeklinde biraraya gelir (Khanjani, 2015).

Selüloz kaynaklı hammaddelerden selüloz izolasyon işlemi iki aşamadan oluşur. Birinci aşama, hammaddenin saflaştırması ve homojenizasyonu ön işlemleridir. Bu uygulama, selüloz kaynağina (ahşap, bitkiler, tunikat, algal ve bakteri selüloz kaynağ1 gibi) bağlı olarak değişmektedir (Moon vd., 2011). İkinci aşama, bu "saflaştırılmış" selüloz maddesinin mikrolifler ve / veya kristal bileşenlere ayrilmasını oluşturur. Bu aşamada mekanik işlem, asit hidrolizi ve enzimatik hidroliz gibi farklı işlemler kullanılmaktadır (Siró ve Plackett, 2010).

En bol selüloz içeren hammadde odun ve daha az oranda ylllık bitkilerdir. $\mathrm{Bu}$ ahşap veya bitki hücreleri 10 mikron çapında ve milimetre uzunluğundadır. Bunlar yüksek selüloz miktarına ve nispeten düşük kristal oranına (\%43-65) sahiptirler. Mikrokristal selüloz (MKS), hemiselüloz içerikli hamurun asit hidroliziyle ve alkali ile nötralize edilmesi ile hazırlanır. Nihai parçacıklar yaklaşık $10-50 \mu \mathrm{m}$ çapındadır. Genellikle, MKS agregaları, kompozitlerde kullanım için 1-10 $\mu \mathrm{m}$ uzunluğunda daha küçük parçacıklara ayrılır. Selüloz parçacıklarının bir başka türü, ahşap ve bitki lifi pulplarının mekanik olarak işlenmesiyle üretilen mikrolif selülozdur (MLS). Genişlik ve uzunlukları sırasıyla 10-100 nm ve $0,5-10 \mu \mathrm{m}$ olup yüksek en/boy oranına sahiptirler ve hem amorf hem de kristal bölgeler içerirler. Nanolif selülozun (NLS) boyutları ise sirasiyla 4-20 nm ve 500-2000 nm'dir. NLS'nin MLS'den farklılaşması, daha ince parçacık çapı üreten lifli yapı sağlama işlemine dayanır (Moon 
vd., 2011). Mert vd. (2011) misir yapraklarından elde edilen liflerin daha büyük yapilı lifler olmasindan dolay1, nispeten daha kisa liflere sahip olan misır koçanindan elde edilen liflerden daha az su tuttuğunu bildirmişlerdir. Dolayisıyla aynı bitkiden ancak farklı kısımlarından elde edilen liflerinde farklı özelliklere sahip olduğu anlaşılmaktadır.

Nanoselüloz kristalleri kâğıt sanayii uygulamalarında temel olarak 2 dezavantaja sahiptir. Bunlardan birincisi, iki nanokristal arasinda güçlü hidrojen etkileşimlerine yol açan ve jel benzeri yap1 oluşturan hidroksil gruplarının sayısıdır. İkinci dezavantaj ise, kâğıt kaplama veya kompozit üretimi gibi çeşitli uygulamalarda kullanımını sınırlayan, bu malzemenin yüksek hidrofillikliğidir (Khanjani, 2015). Nitekim Mert vd. (2011) üretmiş oldukları nano liflerin çok fazla su tuttuğunu ve gida uygulamalarında bu durumun sorun oluşturduğunu belirlemişlerdir. Bu nedenle selülozun modifikasyonu tercih edilen bir işlem olarak ortaya çıkmaktadır.

Selüloz nanoparçacıklarının yüzey yapısı (kimyası) öncelikle, doğal selülozik hammaddeden nanopartiküller hazırlamak için kullanılan ekstraksiyon işlemi ile belirlenir. Selülozun ekstraksiyonu sırasında sülfürik asit muamelesiyle selüloz nanoparçacıklarının yüzeyinde sülfat esteri oluşturulabilir (selüloz sülfatasyonu). Selülozun sülfatasyonu ile nanoselüloz dispersiyonunun stabil olması sağlanır. Bu yöntem, kristal yüzey üzerinde sülfat gruplarının zenginleştirilmesine neden olur. Fosforik asit ve hidrobromik asit gibi daha az kullanilan diğer yöntemler de bulunmaktadır. Bir diğer yöntem ise 2,2,6,6tetrametilpiperidin 1-oksil kullanilarak yapilan oksidasyon işlemidir. Bu yöntemde, selülozdaki birincil alkol gruplarını seçici olarak oksitlemek için hipoklorit gibi bir oksidan ve 2,2,6,6Tetrametilpiperidin 1-oksil radikali (katalizör) kullanılır. Bu yöntemle, nanolif haline getirilmiş selülozun birincil alkol grubu karboksilik aside oksitlenir (Khanjani, 2015).

Bir diğer modifikasyon yöntemi ise moleküllerin bir gaz, sıv1 veya çözünmüş katıdan selüloz yüzeyine adsorbe edilmesi yoluyla sağlanır. Sürfaktanların adsorpsiyonu ile nanoparçacıkların kovalent olmayan yüzey modifikasyonları sağlanarak stabilite artısı gerçekleşir. Bu yaklaşım, alkilfenol yapisı bulunduran fosforik asitin monove di-esterlerinden oluşan sürfaktanları kullanan Heux vd. (2000) tarafindan ortaya atılmıştır. Kim vd. (2009) ve Rojas vd. (2009) selüloz nanoparçacıklarını polistiren esaslı kompozitlerde dağıtmak için noniyonik sürfaktan kullanımının uygun olduğunu belirlemişlerdir. Selüloz yüzey modifikasyonunun üçüncü yöntemi, moleküllerin türetilmesi ve/veya kovalent bağlanması yoluyla sağlanır. Selüloz hidroksil gruplarına sahip olmasindan dolay1 alkollerle veya anhidritlerle kimyasal modifikasyonu gerçekleştirilebilmektedir. Bu sayede farklı kimyasallar kullanılarak farklı özelliklerde son ürünler üretilebilmektedir. Selülozik $\mathrm{OH}$ gruplarının sülfirik asit ile reaksiyonu yoluyla sülfat esterlerin oluşması yüzeyin negatif yüklü olmasinı sağlar. Koagülasyon önlemek amaciyla selülozun homojen sülfasyonu, selüloz sülfatlar elde etmek için bir iyonik sıv1 1-bütil-3-metilimidazolyum klorit kullanılarak gerçekleştirilmiştir (Wang vd., 2009). Heterojen sistemin en büyük problemi, amorf bölgelerdeki $\mathrm{OH}$ grupları ile kristal bölgelerdeki $\mathrm{OH}$ grupları arasındaki erişilebilirliktir ve homojen olmayan modifikasyon ile sonuçlanır. Bir başka modifikasyon örneği, polimer ekleme olup, çeşitli özelliklere sahip bir dizi farklı polimer selüloz yüzeyine eklenir. Yüzeyler ayrica kloro ve alkoksi silanlar kullanılarak sililleştirilebilir. Silanlar selüloz yüzeyine kovalent olarak bağlanmaktadır (Andresen vd., 2007).

Selüloz zincir moleküllerinin her bir glukoz birimindeki üç hidroksil grubu selüloz esterleri oluşturmak üzere inorganik ve organik asitler veya asit klorürler ve anhidritler ile reaksiyona girebilir. Polisakkaritlerin en yaygın açilasyonu, heterojen koşullar altında karboksilik asit anhidritler ile sağlanır. Selüloz asetat, katalizör olarak sülfürik asidin kullanımı ile (ağırlıkça\% $15^{\prime}$ e kadar) selülozun asetik asit ve asetik anhidrit karışımı ile modifikasyonu yoluyla üretilmektedir. Selüloz esterlerinin reaktifliği yapıya bağlanan karboksilik asidin zincir uzunluğu arttıkça azalmaktadır (asetik $>$ propiyonik $>$ bütirik asit) (Liu ve Zhang, 2008). 
Sunulan bu çalışmada delignifikasyon işlemi sonrasında mikro-akışkanlaştırma yöntemi ile 3 farklı kaynaktan (Buğday kepeği, mısır koçanı ve ayçiçeği tablası) nanoselüloz lifleri elde edilmiş olup, elde edilen liflerin hidroksil grupları farkl1 zincir uzunluklarına sahip yağ asitleri ve asetik anhidrit ile farklı oranlarda esterleştirilmesinin optimizasyonu çalışmaları yapılmıştır.

\section{MATERYAL-METOT}

\section{Nanoselüloz liflerinin eldesi}

\section{Ligninin uzaklaştırılması}

Buğday kepeği, mısır koçanı ve ayçiçeği tablası $80^{\circ} \mathrm{C}$ sıcaklıktaki $\mathrm{NaOH}$ içeren alkali su ( $\left.\mathrm{pH} 12\right)$ içine konulmuş ve yapıda bulunan ligninin ayrılmasını sağlamak için 48 saat bekletildikten sonra, saf su ile suyun koyu rengi giderilene kadar yıkanmıştır.

\section{Kolloit değitmen ile boyut küçültme işlemi}

Lignini uzaklaştırılmıss lifler kolloit değirmende (IKA Magic Lab, Almanya) boyut küçültme işlemine tabi tutulmuştur. Bu amaçla lifler 10000$11000 \mathrm{dev} /$ dakika dönüss hızına sahip koloit değirmenden 3 defa geçirilerek, boyutları kolloit çözelti oluşturacak düzeylere küçültülmüştür.

\section{Mikroakışkan cihazı ile boyut küçültme işlemi}

Kolloit değirmen ile boyutu küçültülen lifler, yüksek basınçlı bir mikroakışkan cihazından geçirilmiştir. Bu aşamada 14000-15000 psi basinç ile mikro kanallardan geçirilerek mikroakışkan özellik kazanmış ve böylece boyut indirgeme gerçekleştirilmiştir. Elde edilen lifler birimimizde bulunan dondurarak kurutma cihazi ile $(-) 90^{\circ} \mathrm{C}$ 'de vakum altında kurutulmuş ve $(-) 85^{\circ} \mathrm{C}$ 'de saklanmıştur.

\section{Nanoselüloz örneklerinde analizler Lignin, protein ve selüloz tayini}

Bitkisel liflerde lignin tayini TAPPI T 13 m-54 standardına göre (Anonim, 1998) protein içeriği AOAC Official Method 920.87 (AOAC, 1998)'a göre selüloz içeriği ise Kürschner-Hoffner (1969) yöntemine göre belirlenmiştir.

\section{Su tutma kapasitesi tayini}

Bitkisel liflerin su tutma kapasitesi analizi McConnell vd. (1974) tarafindan belirlenen santrifüj metodu kullanılarak belirlenmiştir. Bu amaçla, dondurarak kurutma cihazı ile $-80^{\circ} \mathrm{C}$ ve $0,001 \mathrm{mmHg}$ basınç altında kurutulan örneklerin 1,0 gramı $15 \mathrm{ml}$ distile su ile santrifüj tüpü içinde karıştırıldıktan sonra tüpler yaklaşık 10 dakika çalkalanmıştır. Daha sonra, 30 dakika bekletilmiş ve 3500 devir/dakika hızla 10 dakika santrifüje tabi tutulmuşlardır. Son olarak, üstte kalan sıvı faz ayrıldıktan sonra kalan pellet tartılmıştır. Su tutma kapasitesi g $\mathrm{H}_{2} \mathrm{O} / \mathrm{g}$ kuru selüloz olarak tanımlanmıştır.

\section{Taramalı elektron mikroskobu görüntüleri}

Elde edilen bitkisel liflerin morfolojik yapiları Zeiss/Evo 40 model taramalı elektron mikroskobu yardımıyla belirlenmiştir.

Nanoselüloz yağ asidi esterleri sentezinin optimizasyonu ve analizler

Nanoselüloz yă̆ asidi esterleri sentezinin optimizasyonu

$\mathrm{Bu}$ aşamada Vaca-Garcia ve Borredon (1999) tarafından belirtilen yöntem modifiye edilerek kullanılmış olup bu aşamada kaproik asit (hekzanoik asit, 6:0, erime noktas $-3^{\circ} \mathrm{C}$ ), laurik asit (dodekanoik asit, 12:0, erime noktas $144^{\circ} \mathrm{C}$ ), stearik asit (oktadekanoik asit, 18:0, erime noktas $70^{\circ} \mathrm{C}$ ) ve oleik asit (oktadesenoik asit, 18:1, erime noktas $13^{\circ} \mathrm{C}$ ) kullanılarak farklı özelliklerde ürünlerin eldesi sağlanmıştır.

Bu amaçla 2 g nanoselüloz örneği önce $200 \mathrm{~mL}$ saf su ile daha sonra $80 \mathrm{~mL}$ etanol (2 defa) ile yıkandiktan sonra oda sicaklığında kurutulmuş ve daha önce hazırlanmış olan yağ asidi, asetik anhidrit ve $\mathrm{H}_{2} \mathrm{SO}_{4}$ karışımı içerisine eklenmiş ve $75^{\circ} \mathrm{C}$ 'de belirli sürelerde reaksiyonun gerçekleşmesi sağlanmıştır (glikoz : asetik anhidrit $: \mathrm{H}_{2} \mathrm{SO}_{4}$ mol oranlar1 sirasiyla $1: 6: 0.06$ ) Reaksiyon sonrasında filtrasyon işlemi yapılmış ve elde edilen örnekler $250 \mathrm{~mL}$ metanol ile yikanarak reaksiyona girmeyen yağ asitleri uzaklaştırıldıktan sonra örnekler vakumlu etüvde $60^{\circ} \mathrm{C}$ 'de kurutularak saklanmıştır. 
$\mathrm{Bu}$ aşamada her bir yağ asidi 6 farklı konsantrasyonda $(1-10 \mathrm{~mol})$ kullanılmıs ve reaksiyon 6 farklı sürede $\quad(30-360 \quad \mathrm{dk})$ gerçekleştirilmiş olup nanoselüloz-yağ asidi esterlerinin optimizasyonu Design Expert 8.0.7.1 paket program1 (Stat-Ease Inc., Minneapolis, MN, ABD) ile oluşturulan deneme deseni (D-Optimal Cubic Design) kullanılarak gerçekleştirilmiştir.

\section{Esterleşme derecesinin belirlenmesi}

Üretilen her bir örneğin esterleşme derecesi volumetrik yöntem (Gourson vd., 1999) kullanılarak gerçekleștirilmiștir. $\mathrm{Bu}$ amaçla, üretimi yapilan esterler, $40^{\circ} \mathrm{C}$ 'de 16 saat $0,25 \mathrm{M}$ $\mathrm{NaOH}$ alkollü çözelti ile sabunlaştırıldıktan sonra $\mathrm{N} / 10$ 'luk hidroklorik asit ile titre edilmiş ve reaksiyona giren/girmeyen $\mathrm{NaOH}$ üzerinden aşağıdaki formül kullanılarak esterleşme derecesi belirlenmiştir.

$$
\text { Esterleşme Derecesi }=\frac{\mathrm{M}_{\mathrm{g} \text { tik }}}{\left(\mathrm{M}_{\text {ömek }} / \mathrm{n}_{\mathrm{ya}}\right)-\left(\mathrm{M}_{\mathrm{ya}}-\mathrm{M}_{\mathrm{s}}\right)}
$$

$\mathrm{M}_{\mathrm{glk}}=$ glukoz ünitesinin moleküler ağırlığı (162,14 g)

$\mathrm{M}_{\text {örnek }}=$ Örnek miktarı (g)

$\mathrm{n}_{\mathrm{ya}}=$ yağ asidinin mol sayısı (titrasyonla hesaplanmış)

$\mathrm{M}_{\mathrm{ya}}=$ yağ asidinin moleküler ağırlı̆̆ $(\mathrm{g})$

$\mathrm{M}_{\mathrm{s}}=$ Su molekülünün moleküler ağırlı̆̆ $(\mathrm{g})$

\section{Yağ asitleri kompozisyonu analizi}

Elde edilen ürünlerde bağlanan yağ asitlerinin belirlenmesi amaciyla Christie (1989) tarafindan bildirilen ve Kim ve Liu (1999) tarafindan değiştirilen yağ asitlerinin asidik ortamda transesterifikasyonu metodu kullanılarak nanoselüloz-yağ asidi esterlerinden yağ asidi metil esterleri oluşturulmuştur. Bu amaçla 2 g örnek üzerine $1,2 \mathrm{~mL} \% 1^{\prime}$ lik $\mathrm{H}_{2} \mathrm{SO}_{4}$ (metanolde) ilave edilmiş ve $80^{\circ} \mathrm{C}$ 'de 2 saat bekletilmiştir. Daha sonra üzerine $\% 5$ 'lik $\mathrm{NaCl}$ çözeltisinden $1,4 \mathrm{~mL}$ ilave edilmiş ve ayırma hunisinde $15 \mathrm{~mL}$ hekzan ile 2 kez ekstraksiyon yapılmışıtı. Hekzan fazı üzerine $\% 4$ 'lük $1,2 \mathrm{~mL}$ potasyum bikarbonat ilave edilip sodyum sülfat varlığında vakum altında filtre edilmisstir. Elde edilen esterler daha sonra, DB 23 kapiler kolon $(60 \mathrm{~m} \times 0,25 \mathrm{~mm}$ ve $0,25 \mu$ film kalınlığ1) kullanılarak gaz kromatografisi cihazında (Shimadzu GC-2010plus) analiz edilmiştir. Analiz kapsamında miktar analizi yapabilmek için iç standart olarak margarik asit (17:0) ve taşıyıcı gaz olarak helyum $(1 \mathrm{~mL} / \mathrm{dk})$ kullanılmıştır.

\section{İstatistik analiz}

Çalışma kapsamında elde edilen verilerin istatistiksel değerlendirilmesinde SPSS (SPSS Inc., Chicago, IL) paket programı kullanılmış olup ANOVA analizi uygulanmıştır.

\section{BULGULAR ve TARTIŞMA}

- Lignin, protein, selüloz ve su tutma kapasitesi tayini

Bitkisel liflerde lignin tayini, protein içeriği ve selüloz içeriği belirlenmiş olup sonuçlar Çizelge 1'de verilmiştir. Çizelgeden görüldüğü üzere buğday kepeğinden elde edilen lifin selüloz içeriği $\% 50.878 \pm 0.713$, lignin içeriği $\% 0.343 \pm 0.113$ ve

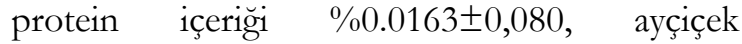
tablasından elde edilen lifin selüloz içeriği $\% 60.973 \pm 0.919$, lignin içeriği $\% 0.350 \pm 0.119$ ve protein içeriği $\% 0.168 \pm 0.080$, mısır koçanından elde edilen lifin ise selüloz içeriği $\% 78.683 \pm 0.521$, lignin içeriği $\% 0.429 \pm 0.121$ ve protein içeriği $\% 0.0818 \pm 0.004$ olarak belirlenmiştir.

Çizelge 1. Nanoliflerin lignin. protein ve selüloz içeriği

Table 1. Lignin. protein and cellulose contents of nanofibers

\begin{tabular}{lcccc}
\hline $\begin{array}{l}\text { Örnek } \\
\text { Sample }\end{array}$ & $\begin{array}{c}\text { Selüloz } \\
\text { Cellulose }\end{array}$ & $\begin{array}{c}\text { Lignin } \\
\text { Lignin }\end{array}$ & $\begin{array}{c}\text { Protein } \\
\text { Protein }\end{array}$ & $\begin{array}{c}\text { Su tutma kapasitesi } \\
\text { Water holding capacity } \\
\left(\mathrm{g} \mathrm{H} \mathrm{H}_{2} \mathrm{O} / \mathrm{g}\right)\end{array}$ \\
\hline BN & $50.878 \pm 0.713^{\mathrm{a}}$ & $0.343 \pm 0.113^{\mathrm{a}}$ & $0.0163 \pm 0.080^{\mathrm{a}}$ & $6.76 \pm 0.033^{\mathrm{a}}$ \\
$\mathrm{AN}$ & $60.973 \pm 0.919^{\mathrm{b}}$ & $0.350 \pm 0.119^{\mathrm{a}}$ & $0.0168 \pm 0.008^{\mathrm{a}}$ & $7.19 \pm 0.066^{\mathrm{b}}$ \\
$\mathrm{MN}$ & $78.683 \pm 0.521^{\mathrm{c}}$ & $0.429 \pm 0.12^{\mathrm{b}}$ & $0.0818 \pm 0.004^{\mathrm{b}}$ & $7.67 \pm 0.057^{\mathrm{c}}$ \\
\hline
\end{tabular}

BN: Buğday kepeğinden elde edilen nanolif, Wheat bran nanofiber

AN: Ayçiçek tablasından elde edilen nanolif, Sunflower tray nanofiber

MN: Misır koçanından elde edilen nanolif, Corncob nanofiber 
Çizelge 1'den görüldüğü üzere Ayçiçek tablasindan elde edilen liflerin $7.19 \pm 0.066 \mathrm{~g}$ $\mathrm{H}_{2} \mathrm{O} / \mathrm{g}$ su, misır koçanından elde edilen liflerin $7.67 \pm 0,057 \mathrm{~g} \mathrm{H}_{2} \mathrm{O} / \mathrm{g}$ su ve buğday kepeğinden elde edilen liflerin $6.76 \pm 0.033 \mathrm{~g} \mathrm{H}_{2} \mathrm{O} / \mathrm{g}$ su tutma kapasitesine sahip olduğu belirlenmiştir. $\mathrm{Bu}$ sonuçlardan anlaşıldığı üzere farklı kaynaklardan elde edilen nanolifler yapı olarak farklı özelliklere sahiptir. Nitekim selüloz içeriği en yüksek olan mısır koçanı lifi en yüksek, selüloz içeriği en düşük olan buğday kepeği en düşük su tutma kapasitesine sahiptir.

Jia vd., (2016) tarafindan yapılan bir çalışmada misır koçanından $\mathrm{NaOH}$ kullanılarak elde edilen selüloz miktarı bizim çalışmamızın sonucuna benzer şekilde \%79.08 olarak belirlenmiştir. Ancak Bardak vd. (2020) delignifikasyon yapılmamış Ayçiçek tablasının \%39.02 selüloz içerdiğini tespit etmişlerdir (lignin içeriği \%17,01). Yine literatürde bulunan bir çalş̧mada delignifikasyon sonrası buğday kepeğinden bizim belirlediğimiz sonuçlardan daha az miktarda
(\%35.2 \pm 0.82$) \quad$ selüloz içeren ürünlerin elde edildiği bildirilmiştir (Behiç vd. 2011). Benzer şekilde Erinç vd. (2018) yapmış oldukları bir çalışmada buğday kepeğinden elde edilen nanoliflerin selüloz içeriğini $\% 35.6 \pm 0.85$ olarak belirlemişlerdir. Sunulan bu çalışmada elde edilen buğday kepeği nanoliflerinin Erinç vd. (2018) tarafindan elde edilen nanoliflerden (su tutma kapasitesi $5.95 \pm 0.25 \mathrm{~g} \mathrm{H}_{2} \mathrm{O} / \mathrm{g}$ ) daha yüksek oranda selüloz içermesi nedeniyle daha yüksek su tutma kapasitesine sahip olduğunu göstermektedir.

\section{Taramalı elektron mikroskobu görüntü analizi}

Elde edilen bitkisel liflerin taramalı elektron mikroskobu görüntülerinden de anlaşıldığı üzere her bir lif kaynağından elde edilen nano lifler benzer şekilde ipliksi yapılardan oluşmaktadır (Şekil 1-3). Bu ipliksi yapılar sayesinde nano liflerin yüksek su tutma kapasitesine sahip olduğu düşünülmektedir.

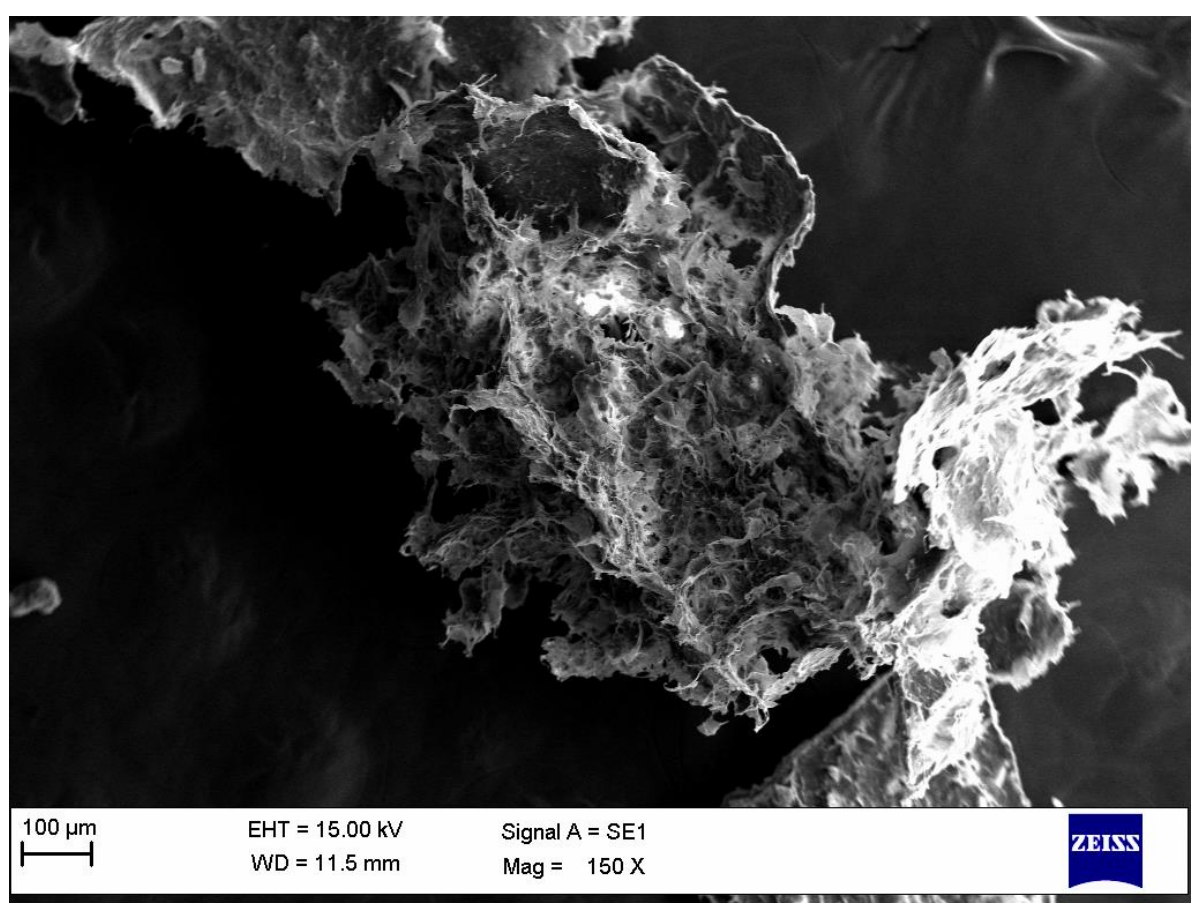

Şekil 1. Ayçiçeği tablasından elde edilen nanoliflerin taramalı elektron mikroskobu görüntüsü Figure 1. Scanning electron microscope image of nanofibers from sunflower tray 


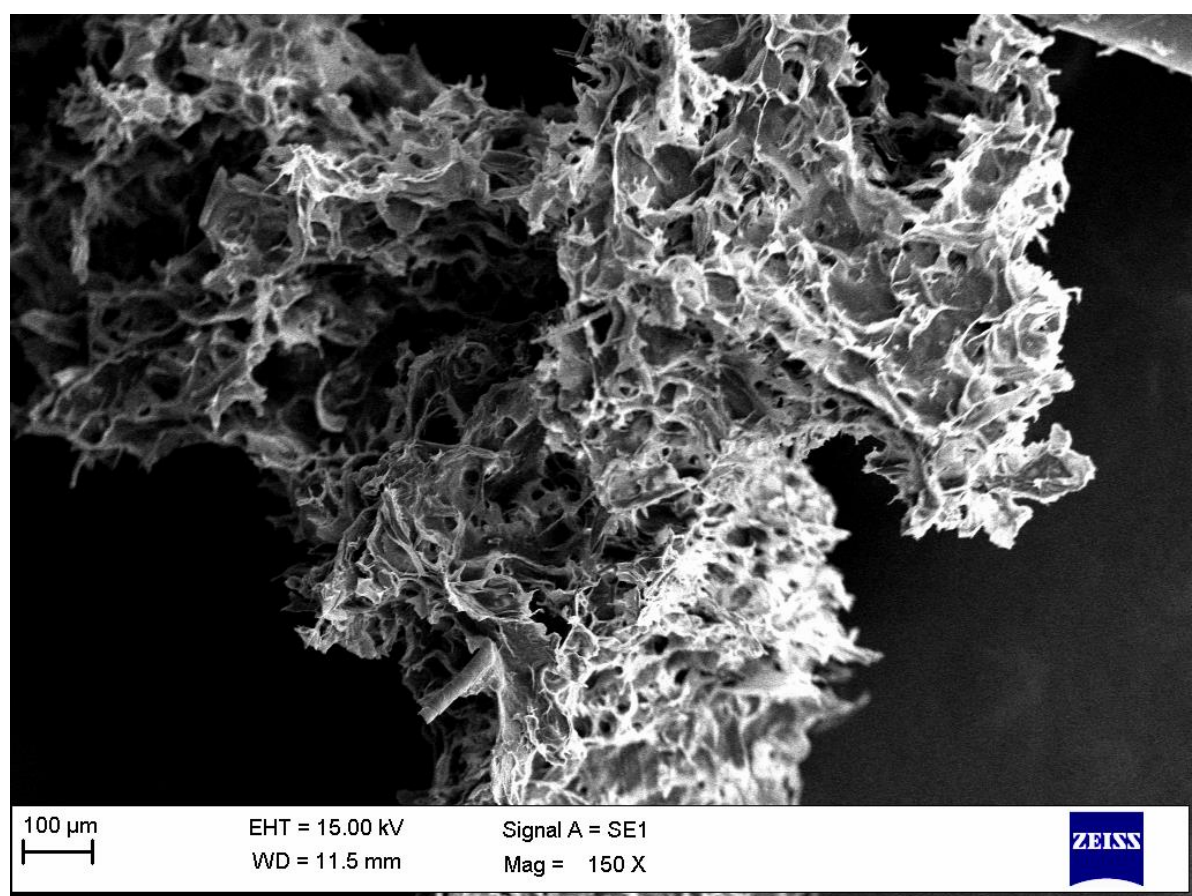

Şekil 2. Buğday kepeğinden elde edilen nanoliflerin taramalı elektron mikroskobu görüntüsü Figure 2. Scanning electron microscopy image of nanofibers from wheat bran

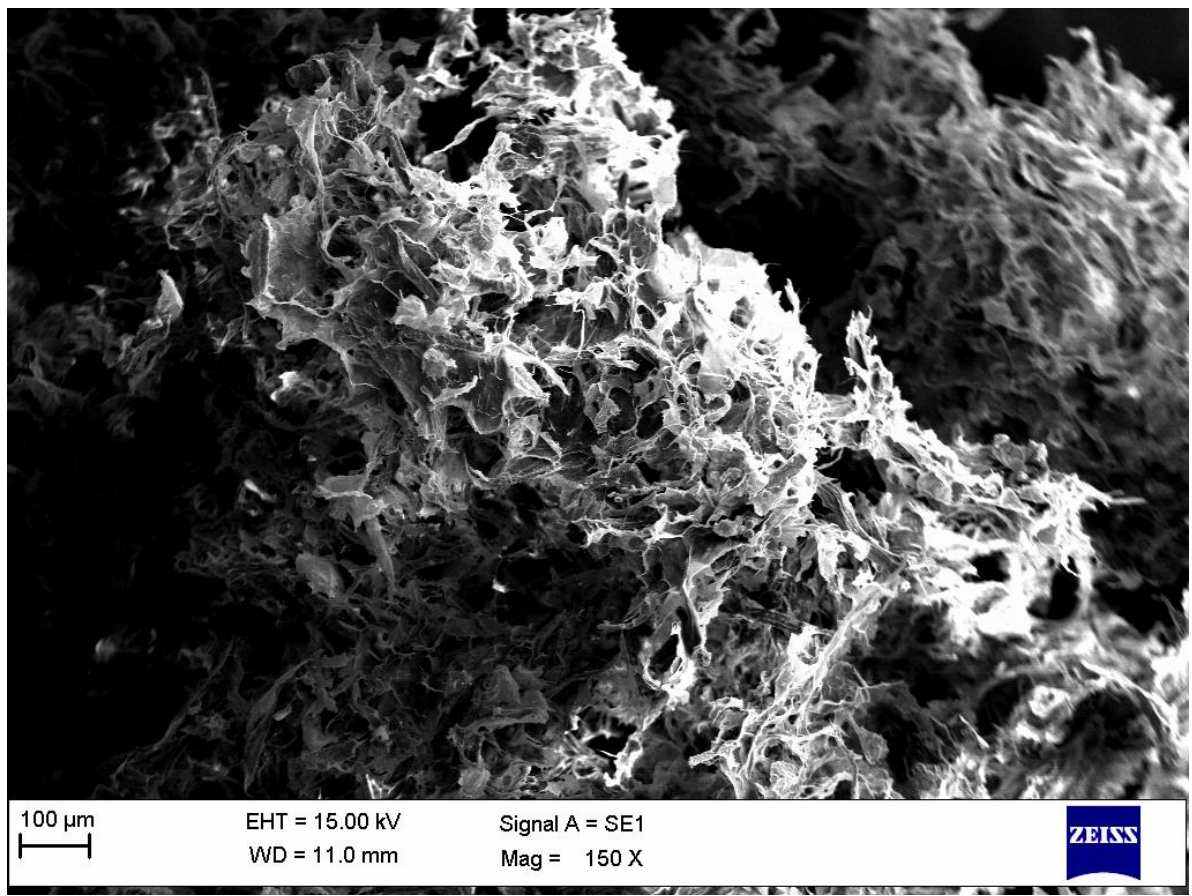

Şekil 3. Mısır koçanından elde edilen nanoliflerin taramalı elektron mikroskobu görüntüsü Figure 3. Scanning electron microscopy image of nanofibers from corncob 


\section{Esterleşme Derecesi}

Şekil 4'de görüldüğg̈ üzere asetik anhidrit ve yağ asitleri ile selüloz esterlerinin oluşumu iki farklı yol izlemekte olup reaksiyon sonunda selülozun yağ asitleri esterleri ve selülozun asetik asit esterleri oluşmaktadır. Literatürde bulunan benzer modifikasyon yöntemi ile gerçekleştirilen birçok çalışmada (Vaca-Garcia ve Borredon, 1999; Zhang vd., 2018) asetik asidin yağ asitlerinden daha fazla oranda ester oluşturduğu ve bu oranın yaklaşı 1.5-2 asetik asit esterlerine karşıllk 1-1.2 yağ asidi esteri olacak şekilde gerçekleştiği, kullanılan yağ asitleri, selüloz türevi ve reaksiyon şartlarına bağlı olarak bu oranların değiştiği bildirilmiştir. Sunulan bu çalışma kapsamında üretilen nanoselüloz-yağ asidi esterlerinin esterleşme dereceleri 0.41-2.99 arasında değişmiş olup üretilen nanoselüloz-yağ asidi esterlerinden uygun yöntemle yağ asidi metil esterleri elde edildikten gaz kromatografisi cihazı ile analiz edilmiş ve literatürden farklı olarak büyük oranlarda asetik asit (0.34-2.47) ve çok düşük oranlarda yağ asidi (0.07-0.55) içerdiği tespit edilmiştir. Bu çalışma sonuçlarının literatürden farklı olmasının temel sebebinin nanolifler içermesinden kaynaklı olduğu düşünülmektedir. $\mathrm{Bu}$ nedenle aynı reaksiyon şartlarında farklı boyutlarda liflerin kullanımı ile farklı esterleşme derecesine sahip ürünlerin elde edileceği anlaşılmaktadır.<smiles>[R]C(=O)O</smiles><smiles>[R]C(=O)OC(C)=O</smiles>

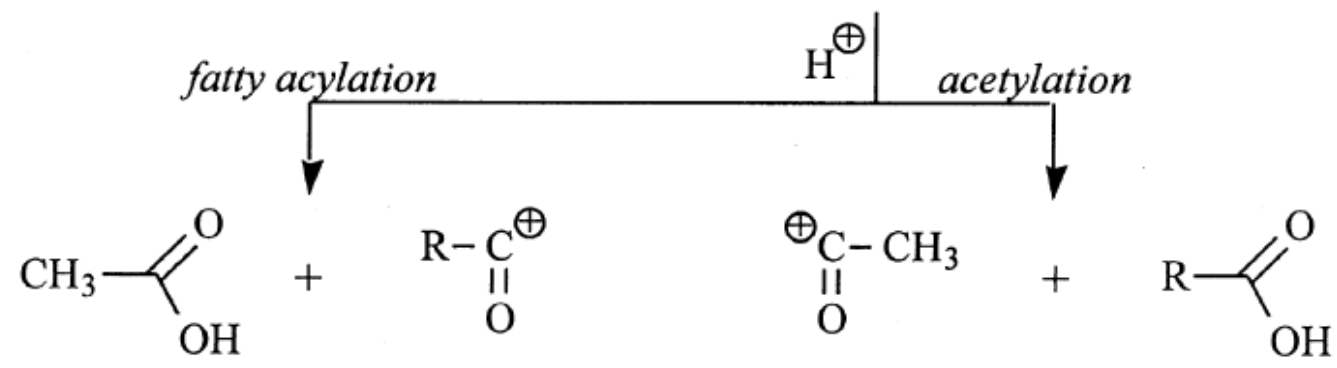

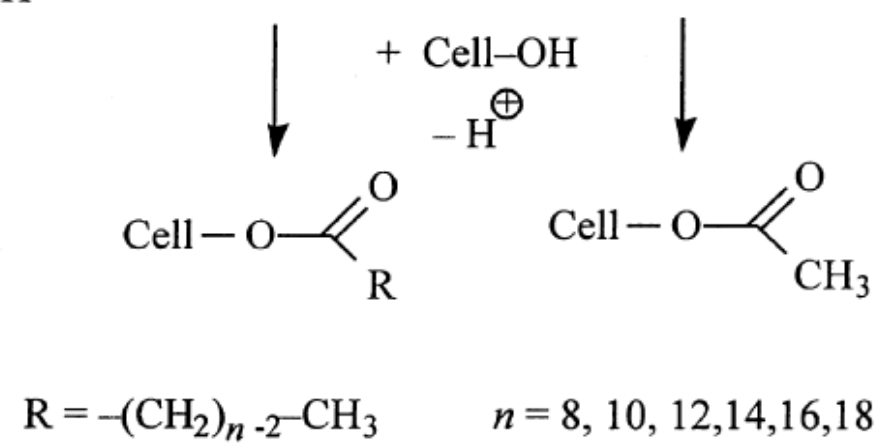

Şekil 4. Yağ asitleri ve asetik anhidrit ile selülozun esterleşme mekanizması (Liu ve Zhang, 2008). Figure 4. Esterification mechanism of cellulose with fatty acids and acetic anbydride (Liu and Zhang, 2008). 
Nanoselüloz yağ asidi esterleri üretimi

Çizelge 2. Elde edilen ürünlerin esterleşme dereceleri (D-Optimal Cubic Design) Table 2. Esterification degrees of the obtained products (D-Optimal Cubic Design)

\begin{tabular}{|c|c|c|c|c|c|c|}
\hline \multirow{2}{*}{$\begin{array}{l}\text { Yağ asidi konsantrasyonu } \\
\text { (mol) } \\
\text { Fatty acid concentration (mole) }\end{array}$} & \multirow{2}{*}{$\begin{array}{l}\text { Süre (dakika) } \\
\text { Time (minutes) }\end{array}$} & \multirow{2}{*}{$\begin{array}{l}\text { Yağ asidi } \\
\text { Fatty acid }\end{array}$} & \multirow{2}{*}{$\begin{array}{l}\text { Lif kaynağ1 } \\
\text { Fiber source }\end{array}$} & \multicolumn{3}{|c|}{$\begin{array}{c}\text { Esterleşme derecesi } \\
\text { Esterification degree }\end{array}$} \\
\hline & & & & $\begin{array}{l}\text { Asetik asit } \\
\text { Acedic acid }\end{array}$ & $\begin{array}{l}\text { Yağ Asidi } \\
\text { Fatty acid }\end{array}$ & $\begin{array}{c}\text { Toplam } \\
\text { Total }\end{array}$ \\
\hline 2 & 30 & C12:0 & AT & 0.43 & 0.09 & 0.52 \\
\hline 2 & 30 & C12:0 & AT & 0.44 & 0.09 & 0.52 \\
\hline 10 & 30 & C12:0 & $\mathrm{BK}$ & 1.11 & 0.24 & 1.35 \\
\hline 2 & 30 & C12:0 & MK & 1.59 & 0.32 & 1.90 \\
\hline 6 & 30 & C12:0 & MK & 1.43 & 0.29 & 1.72 \\
\hline 10 & 30 & C12:0 & MK & 1.29 & 0.27 & 1.56 \\
\hline 1 & 120 & C12:0 & BK & 2.06 & 0.42 & 2.48 \\
\hline 6 & 120 & C12:0 & $\mathrm{BK}$ & 1.63 & 0.33 & 1.95 \\
\hline 10 & 180 & C12:0 & AT & 0.54 & 0.11 & 0.65 \\
\hline 2 & 240 & C12:0 & MK & 1.92 & 0.40 & 2.32 \\
\hline 1 & 300 & C12:0 & AT & 0.74 & 0.15 & 0.89 \\
\hline 8 & 300 & C12:0 & AT & 0.58 & 0.12 & 0.70 \\
\hline 1 & 300 & C12:0 & $\mathrm{BK}$ & 2.25 & 0.46 & 2.71 \\
\hline 6 & 300 & C12:0 & $\mathrm{BK}$ & 2.42 & 0.50 & 2.92 \\
\hline 10 & 300 & C12:0 & BK & 2.29 & 0.47 & 2.76 \\
\hline 1 & 300 & C12:0 & MK & 2.41 & 0.49 & 2.90 \\
\hline 10 & 300 & C12:0 & MK & 2.42 & 0.50 & 2.91 \\
\hline 1 & 30 & C6:0 & BK & 1.30 & 0.25 & 1.55 \\
\hline 6 & 30 & C6:0 & $\mathrm{BK}$ & 1.16 & 0.22 & 1.38 \\
\hline 10 & 30 & C6:0 & $\mathrm{BK}$ & 1.37 & 0.26 & 1.63 \\
\hline 1 & 30 & C6:0 & MK & 1.51 & 0.30 & 1.82 \\
\hline 8 & 30 & C6:0 & MK & 1.39 & 0.27 & 1.66 \\
\hline 8 & 60 & C6:0 & AT & 0.59 & 0.11 & 0.71 \\
\hline 2 & 120 & C6:0 & AT & 0.65 & 0.13 & 0.77 \\
\hline 1 & 180 & C6:0 & BK & 0.37 & 0.07 & 0.44 \\
\hline 6 & 180 & C6:0 & MK & 0.39 & 0.08 & 0.47 \\
\hline 10 & 240 & C6:0 & AT & 1.06 & 0.21 & 1.27 \\
\hline 1 & 300 & C6:0 & AT & 1.20 & 0.23 & 1.43 \\
\hline 6 & 300 & C6:0 & AT & 1.94 & 0.38 & 2.31 \\
\hline 4 & 300 & C6:0 & BK & 1.80 & 0.35 & 2.14 \\
\hline 10 & 300 & C6:0 & BK & 1.92 & 0.37 & 2.29 \\
\hline 2 & 300 & C6:0 & MK & 1.22 & 0.24 & 1.45 \\
\hline 10 & 300 & C6:0 & MK & 1.97 & 0.38 & 2.35 \\
\hline 2 & 30 & C18:1 & AT & 0.40 & 0.09 & 0.49 \\
\hline 6 & 30 & C18:1 & AT & 1.00 & 0.21 & 1.21 \\
\hline 10 & 30 & C18:1 & AT & 1.16 & 0.25 & 1.40 \\
\hline 1 & 30 & C18:1 & BK & 0.35 & 0.07 & 0.42 \\
\hline 1 & 30 & C18:1 & $\mathrm{BK}$ & 0.34 & 0.07 & 0.41 \\
\hline 4 & 30 & C18:1 & MK & 0.83 & 0.17 & 1.00 \\
\hline 4 & 30 & C18:1 & MK & 0.80 & 0.17 & 0.97 \\
\hline
\end{tabular}


Çizelge 2. devam

Table 2. continue

\begin{tabular}{|c|c|c|c|c|c|c|}
\hline \multirow{2}{*}{$\begin{array}{l}\text { Yağ asidi konsantrasyonu } \\
\text { (mol) } \\
\text { Fatty acid concentration (mole) }\end{array}$} & \multirow{2}{*}{$\begin{array}{l}\text { Süre (dakika) } \\
\text { Time (minutes) }\end{array}$} & \multirow{2}{*}{$\begin{array}{l}\text { Yağ asidi } \\
\text { Fatty acid }\end{array}$} & \multirow{2}{*}{$\begin{array}{l}\text { Lif kaynağ1 } \\
\text { Fiber source }\end{array}$} & \multicolumn{3}{|c|}{$\begin{array}{c}\text { Esterleşme derecesi } \\
\text { Esterification degree }\end{array}$} \\
\hline & & & & $\begin{array}{l}\text { Asetik asit } \\
\text { Acedic acid }\end{array}$ & $\begin{array}{l}\text { Yağ Asidi } \\
\text { Fatty acid }\end{array}$ & $\begin{array}{l}\text { Toplam } \\
\text { Total }\end{array}$ \\
\hline 1 & 120 & C18:1 & AT & 0.48 & 0.10 & 0.58 \\
\hline 4 & 120 & C18:1 & BK & 0.75 & 0.16 & 0.91 \\
\hline 10 & 120 & C18:1 & $\mathrm{BK}$ & 0.86 & 0.18 & 1.04 \\
\hline 8 & 180 & C18:1 & AT & 0.87 & 0.18 & 1.05 \\
\hline 10 & 240 & C18:1 & MK & 1.20 & 0.25 & 1.45 \\
\hline 1 & 300 & C18:1 & AT & 1.81 & 0.39 & 2.20 \\
\hline 10 & 300 & C18:1 & AT & 2.47 & 0.52 & 2.99 \\
\hline 1 & 300 & C18:1 & BK & 1.52 & 0.32 & 1.83 \\
\hline 8 & 300 & C18:1 & BK & 2.46 & 0.52 & 2.98 \\
\hline 1 & 300 & C18:1 & MK & 1.36 & 0.29 & 1.65 \\
\hline 6 & 300 & C18:1 & MK & 2.47 & 0.52 & 2.99 \\
\hline 1 & 30 & C18:0 & AT & 0.44 & 0.10 & 0.54 \\
\hline 10 & 30 & C18:0 & $\mathrm{AT}$ & 1.32 & 0.30 & 1.62 \\
\hline 1 & 30 & C18:0 & BK & 0.43 & 0.10 & 0.52 \\
\hline 10 & 30 & C18:0 & $\mathrm{BK}$ & 1.03 & 0.23 & 1.25 \\
\hline 8 & 30 & C18:0 & MK & 1.05 & 0.24 & 1.30 \\
\hline 4 & 120 & C18:0 & AT & 0.82 & 0.18 & 1.00 \\
\hline 10 & 120 & C18:0 & MK & 0.90 & 0.20 & 1.10 \\
\hline 4 & 180 & C18:0 & BK & 0.81 & 0.18 & 0.99 \\
\hline 1 & 240 & C18:0 & MK & 0.82 & 0.19 & 1.01 \\
\hline 1 & 300 & C18:0 & AT & 1.89 & 0.42 & 2.32 \\
\hline 10 & 300 & C18:0 & AT & 2.45 & 0.54 & 2.99 \\
\hline 10 & 300 & C18:0 & AT & 2.44 & 0.55 & 2.99 \\
\hline 1 & 300 & C18:0 & BK & 1.90 & 0.43 & 2.32 \\
\hline 10 & 300 & C18:0 & $\mathrm{BK}$ & 2.44 & 0.55 & 2.99 \\
\hline 10 & 300 & C18:0 & BK & 2.44 & 0.55 & 2.99 \\
\hline 4 & 300 & C18:0 & MK & 2.41 & 0.54 & 2.95 \\
\hline 10 & 300 & C18:0 & MK & 2.44 & 0.55 & 2.99 \\
\hline
\end{tabular}

BK: Buğday kepeği

AT: Ayçiçek tablası

MK: Misır koçanı

$B N$ : Wheat bran

AN: Sunflower tray

MN: Corncob

Çizelge 2'deki veriler Design Expert programı ile işlenerek elde edilen Şekil 5'de görüldüğü üzere tahmin edilen ve gerçek değerler bir birine oldukça yakın bulunmuş olup denemenin $\mathrm{R}^{2}$ değerli 0.9966 olarak belirlenmiştir. Yine Şekil 6'da görüldüğ̈ reaksiyon süresinin artması ve kullanılan yağ asidinin miktarının artması esterleşme reaksiyonunun yüksek oranda gerçekleşmesini sağlamaktadır. Sonuç olarak asetik asit, yağ asitleri ve toplam esterleşme dereceleri açısından maksimum sonuçlar $10 \mathrm{~mol}$ yağ asidi konsantrasyonunda ve $300 \mathrm{dk}$ reaksiyon süresinde elde edilmiştir. 

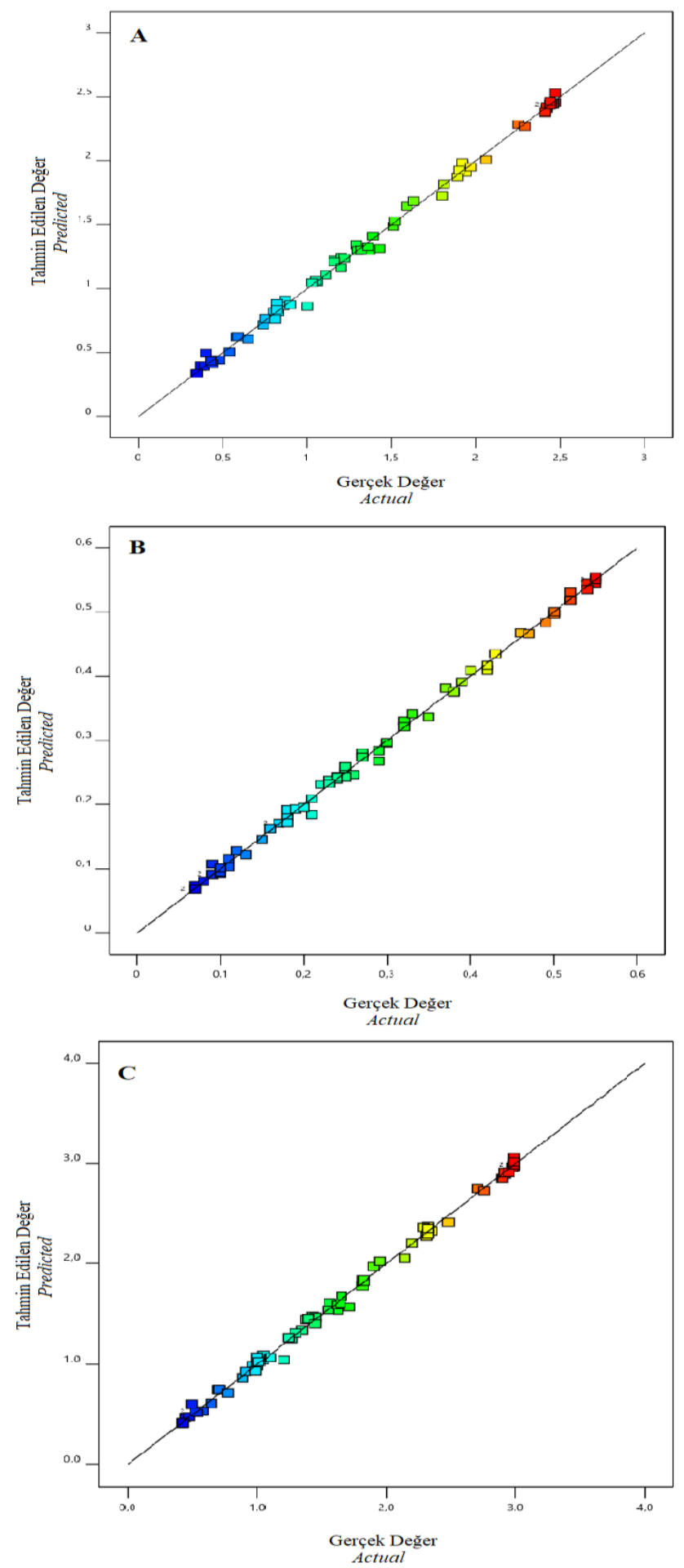

Şekil 5. Tahmin edilen ve gerçek değerler arasındaki korelasyon

Figure 5. Correlation between predicted and actual values

A: Asetik asit ile esterleşme derecesi, esterification degree with acetic acid

B: Yağ asitleri ile esterleşme derecesi, esterification degree with fatty acids

C: Toplam esterleşme derecesi, total esterification degree 

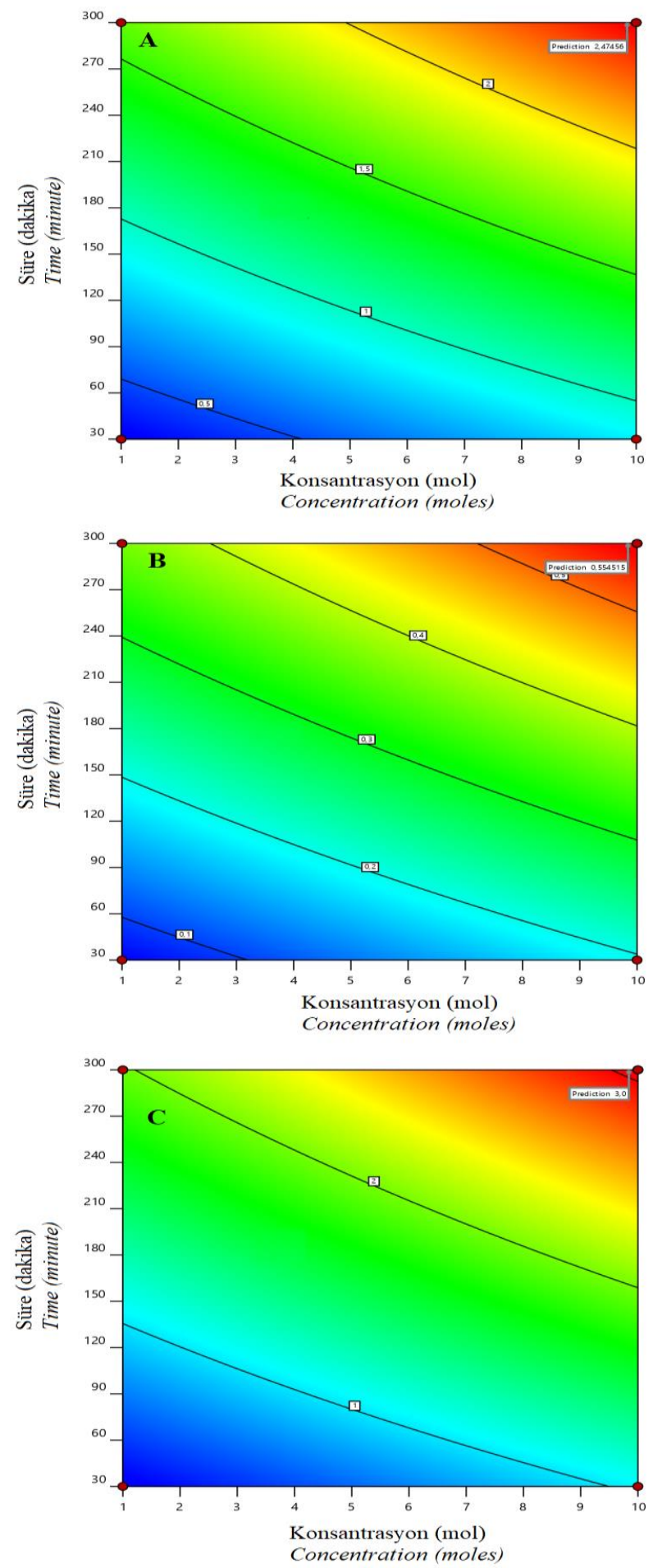

Şekil 6. Reaksiyon süresi ve yağ asidi konsantrasyonu ile esterleşme dereceleri arasındaki ilişki

Figure 6. Relationship between reaction time and fatty acid concentration with degrees of esterification

A: Asetik asit ile esterleşme derecesi, esterification degree with acetic acid

B: Yağ asitleri ile esterleşme derecesi, esterification degree with fatty acids

C: Toplam esterleşme derecesi, total esterification degree 


\section{SONUÇ}

Literatür bilgilerinden anlaşıldığ1 üzere selüloz içeriği yüksek materyal ile yağ asitleri esterleştirilerek elde edilen farklı esterleşme derecesine sahip ürünler farklı özelliklere sahip biyo-bozunur ambalaj maddeleri olarak kullanılabilmektedir. Ancak burada kullanılan lif kaynağı ve yağ asidi çeşidi son ürünün özelliklerini önemli ölçüde değiştirmektedir.

Sunulan bu çalş̧ma sonucunda da farklı bitki kaynaklarından elde edilen selüloz içeriği yüksek nanoliflerin farklı özelliklere (özellikle su tutma kapasitesi) sahip olduğu belirlenmiştir. Çalışmanın devamında nanoliflerin farklı yağ asitleri ve asetik anhidrit ile $\mathrm{DMAc} / \mathrm{LiCl}$ ortaminda farklı derecelerde esterleştirilmesi sağlanmış olup son ürünlerin farklı oranlarda hidrofilik ve lipofilik gruplara sahip olduğu (esterleşme dereceleri 0.412.99) tespit edilmiştir.

Çalışmalar kapsamında reaksiyon süresinin ve kullanılan yağ asidi miktarının arttırılması, esterleşme reaksiyonunun yüksek oranda gerçekleşmesini sağlamış olup maksimum esterleşme derecesi olan 3 değerine (ortalama 2.45 asetil grubu ve 0.55 yağ asidi) ulaş1lmıştır. Maksimum esterleşme derecesi $10 \mathrm{~mol}$ yağ asidi varlığında $90^{\circ} \mathrm{C}$ de gerçekleştirilen 300 dakikalık reaksiyon sonrasında gerçekleşmiştir. Çalışma sonuçlarından anlaşıldığı üzere reaksiyon süresinin ve kullanılan yağ asidi miktarının artması esterleşme reaksiyonlarının oluşumunu arttırmış ancak yağ asitlerinin nanoselüloz lifleri ile esterleşme derecesi oldukça düşük bulunmuştur.

\section{ÇIKAR ÇATIŞMASI}

Yazarların makale ile ilgili başka kişiler veya kurumlar ile çıkar çatışması bulunmamaktadır.

\section{YAZAR KATKILARI}

BM farklı kaynaklardan nanoliflerin üretimini, HE ve ÖE nanoliflerin esterleştirme reaksiyonlarını ve analizlerini gerçekleştirmiştir. AÖ ve tüm yazarlar sonuçların yorumlanmasında katkıda bulunmuştur. Tüm yazarlar tarafindan makalenin son hali okunmuş ve onaylanmıştır.

\section{TEŞEKKÜR}

Yazarlar, projeye destek sağladığı için TÜBİTAK'a (TOVAG 118O315) teşekkür eder.

\section{KAYNAKLAR}

Andresen, M., Stenstad, P., Møretrø, T., Langsrud, S., Syverud, K., Johansson, L. S., Stenius, P. (2007). Nonleaching antimicrobial films prepared from surface-modified microfibrillated cellulose, Biomacromolecules, 8: 2149-2155.

Anonim. (1998). Tappi Test Methods, Tappi Press, Atlanta, Georgia.

AOAC. (1998). Official methods of nalysis. (16th ed.) Arlinghton, VA: Association of Official Analytical Chemists.

Bardak, S., Nemli, G., Bardak, T., Peker, H., Özcan, M. (2020). Ayçiçek Tablasının Yonga Levha Endüstrisinde Kullanilabilme Olanaklan, Bartın Orman Fakïltesi Dergisi, 22 (2): 485-499.

Christie, W.W. (1989). The preparation of derivatives of fatty acids. Ch. 4 in Gas Chromatography and Lipids: A Practical Guide", Oily Press, 65-68.

Erinc, H., Mert, B., Tekin, A. (2018). Different sized wheat bran fibers as fat mimetic in biscuits: Its effects on dough rheology and biscuit quality. Journal of Food Science and Technology, 55: 39603970 .

Gourson, C., Benhaddou, R., Granet, R., Krausz, P., Verneuil, B., Branland, P., Chauvelon, G., Thibault, J. F., Saulnier, L. (1999). Valorization of maize bran to obtain biodegradable plastic films, Journal of applied polymer science, 74(13): 30403045 .

Heux, L., Chauve, G., Bonini, C. (2000). Nonflocculating and chiral-nematic self-ordering of cellulose microcrystals suspensions in nonpolar solvents. Langmuir, 16: 8210-8212.

Jia, F., Liu, H., Zhang, G. (2016). Preparation of carboxymethyl cellulose from corncob, Procedia Environmental Sciences, 31: 98-102.

Khanjani, P. (2015). Cellulose-based superhydrophobic surfaces and dynamics of coupled chemical systems, Aalto Üniversitesi 
Uygulamalı Fizik Bölümü Lisans Tezi, Espoo, Finlandiya.

Kim, J., Montero, G., Habibi, Y., Hinestroza, J. P., Genzer, J., Argyropoulos, D. S., Rojas, O. J. (2009). Dispersion of cellulose crystallites by nonionic surfactants in a hydrophobic polymer matrix, Polymer Engineering \& Science, 49(10): 20542061.

Kim, Y.J. and Liu, R.H. (1999). Selective increase in conjugated linoleic acid in milk fat by crystallization, Journal Food Science, 64: 792-795.

Kondo, T. (1997). The relationship between intramolecular hydrogen bonds and certain physical properties of regioselectively substituted cellulose derivatives, Journal of Polymer Science Part B: Polymer Physics, 35(4):717-723.

Krässig, H. A. (1992). Cellulose: Structure, accessibility, and reactivity, Cellulose (Copyrightc 1993 Gordon and Breach Science).

Kürschner, K., Hoffner A. (1969). Ein neues Verfahren zur Bestimmung der Zellulose in Itolzern und Zellsoffen, Technologie und Chemie der Papier, Zellstoff-Fabrilation, 26:125-139, Germany.

Liu, G., and Zhang, G. (2008). Periodic swelling and collapse of polyelectrolyte brushes driven by chemical oscillation, The Journal of Physical Chemistry B, 112(33):10137-10141.

McConnell, A. A., Eastwood, M. A., Mitchell, W. D. (1974). Physical characteristics of vegetable foodstuffs that could influence bowel function, Journal of the Science of Food and Agriculture, 25:14571464.

Medronho, B., Romano, A., Miguel, M. G., Stigsson, L., Lindman, B. (2012). Rationalizing cellulose (in) solubility: reviewing basic physicochemical aspects and role of hydrophobic interactions, Cellulose, 19(3):581-587.
Mert, B., Tekin, A., Erinç, H., Koçak, G., Bigikoçin, E., Ketenoğlu, O., Şahin, E. (2011). Bitkisel Kökenli Atıklardan Mikro-Akışkan Yöntemiyle Nano boyutlarda Reoloji Düzenleyicilerin Üretilmesi: Emülsiyonlarda, kolloitlerde ve Hamur Ürünlerinde Kullanılması, TUBİTAK Proje No: 108M169.

Moon, R. J., Martini, A., Nairn, J., Simonsen, J., Youngblood, J. (2011). Cellulose nanomaterials review: structure, properties and nanocomposites. Chem. Soc. Rev., 40:3941-94.

Rojas, O. J., Montero, G. A., Habibi, Y. (2009). Electrospun nanocomposites from polystyrene loaded with cellulose nanowhiskers, Journal of Applied Polymer Science, 113(2): 927-935.

Siró, I., Plackett, D. (2010). Microfibrillated cellulose and new nanocomposite materials: a review, Cellulose, 17(3), 459-494.

Vaca-Garcia, C., Borredon, M.E. (1999). Solventfree fatty acylation of cellulose and lignocellulosic wastes. Part 2: reactions with fatty acids, Bioresource Technology, 70:135-142.

Wang, Z. M., Li, L., Xiao, K. J., Wu, J. Y. (2009). Homogeneous sulfation of bagasse cellulose in an ionic liquid and anticoagulation activity, Bioresource Technology, 100(4):1687-1690.

Wisniak, J. (2004). Anselme Payen. Educ. Quimica, 16:578-579.

Zhang, Y., Wei, L., Hu, H., Zhao, Z., Huang, Z., Huang, A., Shen, F., Liang, J., Qin, Y. (2018). Tribological properties of nano cellulose fatty acid esters as ecofriendly and effective lubricant additives, Cellulose, 25: 3091-3103. 